\title{
Restarting for the thrill: Behavioural addiction to entrepreneurship
}

\author{
Ndivhuho Tshikovhi, Farai Dziike, Sibusiso Moyo
}

\begin{abstract}
A B S T R A C T
Objective: The aim of the article is to highlight the behavioural addiction to entrepreneurship by entrepreneurs. Research Design \& Methods: We followed a qualitative design in order to ascertain the publications to date with regards to behavioural addiction to entrepreneurship.

Findings: The study found that there seems to be a behavioural addiction to entrepreneurship by serial and habitual entrepreneurs, who continuously receive incentives from entrepreneurship development agencies without tangible businesses.

Implications \& Recommendations: The implication of the study is that so many genuine entrepreneurs are overlooked for serial and habitual entrepreneurs because they seem to have experience in acquiring incentives without succeeding in running businesses. We recommend that entrepreneurship development agencies need to be aware of the behavioural addiction to entrepreneurship and monitor sponsored entrepreneurs on an annual basis.
\end{abstract}

Contribution \& Value Added: The study brings about a novel angle in the entrepreneurship literature, whereby the success rate is overemphasized due to the benefits of entrepreneurship in creating jobs. But we highlight the need to evaluate and monitor entrepreneurs as they benefit from incubators, funding and mentorships.

\begin{tabular}{|c|c|}
\hline Article type: & conceptual article \\
\hline Keywords: & $\begin{array}{l}\text { Entrepreneurship, Habitual Entrepreneurs, Serial Entrepreneurs, Behavioural Addiction, } \\
\text { Incentives }\end{array}$ \\
\hline JEL codes: & J23, L26, M13 \\
\hline Received: 18 April 2021 & Accepted: 30 June 2021 \\
\hline
\end{tabular}

Suggested citation:

Tshikovhi, N., Dziike, F., \&Moyo, S. (2021). Restarting for the thrill: Behavioural addiction to entrepreneurship. International Entrepreneurship Review, 7(3), 37-46. https://doi.org/10.15678/IER.2021.0703.03

\section{INTRODUCTION}

Recent estimates by venture capitalists in developed and developing nations suggest that nine out of ten firms fail within the first to the second year of operation (Sarasvathy et al., 2013). What seems not to be considered or reported might be the number of unsuccessful entrepreneurs who are likely to start another venture. One might argue that entrepreneurs who keep on applying for funding and starting new ventures as soon as they run out of funding from a previous grant on a former venture, are addicted to this cycle. However, addiction to entrepreneurship as a condition towards one's inability to resist starting new ventures despite repeated failures is reviewed in this study as a behavioural addiction to entrepreneurship. Keskin et al. (2015) suggest that entrepreneurship has become a central discussion point for policymakers and economists alike. Thus, expanding the serial entrepreneurship inquiries towards understanding key factors that influence individual behaviour is imperative. Although there is some dwindling literature in this phenomenon, substantial knowledge about the behaviour of entrepreneurs is lacking.

Gottschalk et al. (2017) argue that policymakers should discourage second chance entrepreneurs as they are more likely to fail than highly skilled entrepreneurs. The main argument by Gottschalk et al. (2017) in their paper titled "The Impact of Habitual Entrepreneurial Experience on New Firm Closure 
Outcomes"is that low-ability entrepreneurs are addicted to their failures in a way that they do not acknowledge their inability to succeed. Instead, they find ways to shift the blame towards others in order for them to sustain their self-esteem and return to entrepreneurship. Shane (2009) echoed similar thoughts in his paper, "Why Encouraging More People to Become Entrepreneurs is Bad Public Policy". Although the argument is categorically clear, crucially what Shane (2009), Gottschalk et al. (2017), as well as Gerpott and Kieser (2017) assert is that, despite the low success rate of entrepreneurial activities, public policy in many countries still insists on providing entrepreneurial incentives.

The entrepreneur incentivizing perspective by policymakers arises at the backdrop of regressing economies, rising unemployment, and ever-advancing technologies and mechanization (Shane, 2009). Thus, policy encourages throwing as many resources as possible to entrepreneurs through various business acceleration programs. Hence repeat unsuccessful entrepreneurs tend to jump from one program to another, thus feeding their addiction. Pretorius and Le Roux (2011) revealed that there are some key observations about an entrepreneur, the preconditions and causes associated with his successive failures, in their report on "Successive Failure, Repeat Entrepreneurship and no Learning: A Case Study".

Spivack et al. (2014) emphasized the underlying psychological symptoms of behavioural addiction to entrepreneurship. Additionally, Spivack et al. (2014) argue that behavioural addiction to entrepreneurship can contribute to either positive or negative outcomes. However, in this study, the adverse outcomes are emphasized. The study aims to highlight the essential but yet neglected fact that there is a possibility of behavioural addiction to entrepreneurship by serial or habitual entrepreneurs. This means that literature about the whole set of entrepreneurs who are not perceived as addicted to entrepreneurship are excluded from this study.

This phenomenon is reasonably relatable to workaholism, which may result in further working opportunities such as promotions and appraisals (Spivack et al., 2014).There are identical similarities between workaholism and addiction to entrepreneurship. Weiner (1985) alluded to these factors as a matter of ability and effort. On an individual level, Weiner (1985)examined in attribution theory what motivation and emotion towards achievements tell us about failed entrepreneurs. Moreover, the feeling of success could lead to emotional expressions, such as anger, gratitude, guilt, hopelessness, pity, and shame (Weiner, 1985). For instance, Weiner (1985) gave an example that an overachiever might indicate that he or she wants to take time from work but cannot control his or her work habits. Despite the work done not being satisfactory. The motivational factors of entrepreneurs who repeatedly fail sought to fulfil are related. Inasmuch as social acceptance and rejection of someone's physical appearance, repeated entrepreneurs are aware of these factors.

Block (2008) identified four critical symptoms of behavioural addiction as excessive use, withdrawal, tolerance and negative repercussions. In the Spivack et al. (2014) study, both participants were found to be eager to return to entrepreneurship activities despite having failed five and six times each. The excerpts from the interviews with the study participants showed that both were entangled in the four symptoms described by Spivack et al. (2014).

This paper seeks to make this critical yet neglected contribution to entrepreneurship studies. Since several studies are concerned with either theory-building or theory-testing, thus this study conceptually explores behavioural addition to entrepreneurship as follows: Literature analysis pertaining to behavioural addiction to entrepreneurship is discussed. A literature matrixis developed to track publications concerning this topic to date. Thereafter, entrepreneurship, habitual, and serial entrepreneurs' dynamics are discussed, as well as public policy encouraging repeated failure. The last section will extend the discussion by providing a conceptual thought for further exploration of behavioural addiction to entrepreneurship.

\section{METHODS AND MATERIALS}

The study adopts a conceptual data gathering, whereby literature pertaining to BAE (Behavioural Addiction to Entrepreneurship) is analyzed. We searched papers that discussed behaviour, addiction, entrepreneurship by serial and/or habitual entrepreneurs in the last ten years. The search resulted in countable papers, which were both empirical and theory-based. We applied literature metrics to iden- 
tify the research argument and method used in order to justify this study's main argument. This method allowed us to find papers that rigorously debated the BAE phenomenon to the latter. It is not surprising that almost all papers were critical of the entrepreneur that does not thrive in the long run since this paper argues that entrepreneurship research less entertains those entrepreneurs to date. Therefore, the objective of this study was to create an awareness for BAE. It is apparent from the conceptual data work that this is not a well-researched phenomenon.

\section{LITERATURE REVIEW AND THEORY DEVELOPMENT}

In this section, we highlight the foundation of entrepreneurship, the behavioural aspects that influence the later and the individual entrepreneur from serial and habitat perspectives related to Behavioral Addition to Entrepreneurship. The addiction to entrepreneurship in this instance is viewed from the ideation, funding applications and to the actual practice. Behavioural Addiction to Entrepreneurship (BAE) refers to persistent entrepreneurial activities, notwithstanding falling upon each attempt (Sarasvathy et al., 2013). Several scholars (cf. Gunnarsson et al., 2007; Logan et al., 2009) who studied entrepreneur's mental health in Denmark, Sweden, United States of America and Britain found that mental health of entrepreneurs shares a common denominator, whereby entrepreneurs suffered poor job satisfaction and poor health (Louie, 2016). Thus, inductive and deductive approaches have been followed by several researchers, as shown in table 1.

There is a consensus in the literature whether the venture created by an entrepreneur succeeded or not; there was a learning process that took place. According to Gompers et al. (2006), entrepreneurs who have a failure track record are likely to benefit the firm by the experience they possess. While entrepreneurs cannot quickly transfer their experience due to the high level of uncertainty in entrepreneurship (Gottschalk et al., 2017), several studies suggest that prior entrepreneurial activity results in more excellent knowledge and experience, which can be easily transferred to a new firm. Thus, generating an assumption that past entrepreneurial experience is an asset for future performance. The entrepreneur does not always have the internal locus of control or the self-awareness to acknowledge his/her own incompetence in certain areas that could have contributed to failure. Such unawareness may be problematic when these entrepreneurs start a new venture. Hence, this turns into a normalized habit that the entrepreneur subconsciously accepts. Thus, behavioural addiction to entrepreneurship is overlooked in literature and an analysis on the literature confirms this claim.

It is evident from table 1 that behavioural addiction to entrepreneurship has not received adequate scholarly attention despite the promotion of serial entrepreneurs by incentives in the hope that they will restart without the stigma of failure. For instance, European countries have launched new programs to promote a fresh restart of ex-entrepreneurs (Rocha et al., 2015). While in more recent literature (meaning last 5 to 10 years), there has been increasing interest in the dynamics of serial entrepreneurship processes, substantial knowledge about the behaviour of entrepreneurs is lacking.

\section{Entrepreneurship as a concept}

Schumpeter (1950) described entrepreneurship as something that creates new processes, puts underutilized resources to new uses, initiates the formation of new industries, and otherwise unleashes "gales of creative destruction" (p. 83). Scholars have often described entrepreneurship as something functional. Although it comes with challenges that can be social and individually detrimental. The oversight of entrepreneurship enthusiasts is a failure. Entrepreneurship, from an individual's perspective, requires endurance, intelligence, and motivation (Louie, 2016). Understanding the entrepreneur's well-being and challenges in entrepreneurship can promote high performance.

Entrepreneurship is defined as the process of engaging in starting a venture, including bearing the risks associated with it(Gartner, 1988). In general, entrepreneurship literature emphasis is placed on the link between economic growth and job creation. However, the negative consequences, such as the failure rate in entrepreneurship, are less entertained. Only recently do we find scholars such as Gerpott and Kieser (2017) provoking the entrepreneurship facade. The main argument of Gerpott and Kieser (2017) essay on the "charisma of an entrepreneur" disentangles the characteristics of entrepreneurs 
as a motivational factor that attracts and keeps the entrepreneurship ideology going without tangible success. Whereas in this paper we view entrepreneurship as a process of venture creation.

Table 1. Selected literature of the subject from 2010-2020

\begin{tabular}{|c|c|c|}
\hline Author(s) & Argument & Method \\
\hline Spivack et al. (2014) & Habitual entrepreneurs' behavioural addition to entrepreneurship. & Case study \\
\hline Keskin et al. (2015) & Entrepreneurship is addictive, similar to gambling and the internet. & Theoretical \\
\hline Brandstätter (2011) & Analysis of personality traits in entrepreneurship. & Theoretical \\
\hline Louie (2016) & There are mental health issues in entrepreneurship. & Essay \\
\hline Carruthers et al. (2019) & $\begin{array}{l}\text { The relationship between entrepreneurial competency and their en- } \\
\text { trepreneurial action. }\end{array}$ & Empirical \\
\hline Rocha et al. (2015) & $\begin{array}{l}\text { Are serial entrepreneurs performing better, or they are in a selected } \\
\text { group of high achievers. }\end{array}$ & Empirical \\
\hline Invernizzi et al. (2017) & $\begin{array}{l}\text { To analyze any relationship between overconfidence and the charac- } \\
\text { teristics of an entrepreneur and the firm. }\end{array}$ & Empirical \\
\hline Gerpott and Kieser (2017) & Entrepreneurship ideology and charismatic entrepreneurs. & Essay \\
\hline Spivack (2020) & $\begin{array}{l}\text { To determine the characteristics of the particularly vulnerable indi- } \\
\text { viduals susceptible to the formation of an addiction to entrepreneur- } \\
\text { ship. }\end{array}$ & Theoretical \\
\hline Stephan (2018) & Entrepreneurs' mental health and well being & Empirical \\
\hline $\begin{array}{l}\text { Wright and Westhead } \\
(2016)\end{array}$ & Compilation of chapters on habitual entrepreneurs. & Mixed \\
\hline Bouckaert et al. (2011) & Restarters are usually bankrupt in Flanders, Belgium. & Empirical \\
\hline Sarasvathy et al. (2013) & What is known about the success and failure of an entrepreneur? & Empirical \\
\hline Gottschalk et al. (2017) & $\begin{array}{l}\text { Habitual entrepreneurs are just as likely as novice entrepreneurs to } \\
\text { fail. }\end{array}$ & Empirical \\
\hline $\begin{array}{l}\text { Lafontaine and Shaw } \\
\text { (2016) }\end{array}$ & What skills lead to entrepreneurship. & Empirical \\
\hline Thomas et al. (2020) & $\begin{array}{l}\text { Examined substance addiction as a core antecedent in the develop- } \\
\text { ment of entrepreneurship addiction. }\end{array}$ & Mixed \\
\hline Tipu (2020) & Entrepreneurial reentry after failure & Theoretical \\
\hline
\end{tabular}

Source: own study.

Shane (2009) echoed the flawed buzz of entrepreneurship, arguing that each new firm in the United States creates new jobs, but these jobs are not sustained two years after new entry due to failure by entrepreneurs. Thus, public policy and entrepreneurship should focus on established entrepreneurs than repeated entrepreneurs(Shane, 2009). The understanding of the difference in entrepreneurs, for instance, charismatic, habitual, and serial, plays a role in determining behavioural addiction to entrepreneurship. Ucbasaran et al. (2003) argue that the extent to which individuals would retard or speed up their reentry into entrepreneurship is influenced by their past experiences of either success or failure.

Incubation hubs, acceleration programs and many more such programs have been in the centre of entrepreneurship promotion, but very few acknowledged the number of failure rate by entrepreneurs. The success rate of incubators is evident in different countries such as New Zealand (87\%), the United States of America (85\%) and Germany (90\%), while South Africa and Brazil both have an $80 \%$ success rate. Besides the success rate of businesses incubation, the failure rate of entrepreneurial activities incubated is alarmingly as high as $90 \%$ (Muriithi et al., 2018).

\section{Habitual entrepreneurs}

Habitual entrepreneurs are entrepreneurs who have started several enterprises (Ucbasaran et al., 2010). It is worth noting that habitual entrepreneurs can be divided into two, that is, habitual starters, as those who start several entities, and habitual acquirers, as those who purchase several entities. Ucbasaran et al. (2010) used a case study approach to distinguish similarities between habitual starters and habitual acquirers. Spivack et al. (2014) reviewed the probability of habitual entrepreneurs as a potential case of 
behavioural addiction to entrepreneurship. In unmasking the entrepreneur, Jones and Spicer (2009) debate about who is really an entrepreneur, in their thought-provoking book. In this book, the authors argue that there are different types of entrepreneurs. However, what the authors do not acknowledge seems to be a possible addiction of entrepreneurs who keep on starting new ventures.

Wright and Westhead (2016) detected habitual entrepreneurs to be "highly prevalent in the United Kingdom, Unites States of America, Finland, Australia, Norway, Ghana, Sweden, and Malaysia" (p. 5). Despite Ghana and Malaysia, the latter are referred to as developed economies. In South Africa, there is the "so called" tenderpreneurs, these are people who chase the grant, tenders and funding as far as possible without making an impact in terms of job creation, the economic growth as anticipated by the government. Therefore, both developed and developing nations might have this phenomenon and therefore it is worthwhile topic and construct to consider.

\section{Serial entrepreneurs}

Serial entrepreneurs are individuals who have closed or sold a business in which they had a minority or majority shares ownership; simultaneously, they own shares or purchased shares independently in another venture (Westhead et al., 2005). The difference between habitual and serial entrepreneurs is narrowly defined in the literature. Prior business ownership may be viewed as a specific human capital in entrepreneurship (Westhead et al., 2005). The specific human capital in the serial entrepreneur may be in the form of managerial or financial skills that are useful within startups (Amaral et al., 2011).

Serial entrepreneurs tend to focus on achieving a particular goal and exhibit attitudes and behaviour associated with reducing uncertainty (Wright et al., 1997). In addition, they also own new firms with a high risk of liabilities (Westheadet al., 2005). Although there is an apparent significance in the contribution that serial entrepreneurs are likely to bring into a new venture. There is also a question of quality than quantity of the impact of the previous independent business ownership.

Serial entrepreneurs can always re-enter the entrepreneurship environment, whether in a new venture or as consultancies based on their experience (Amaral et al., 2009). Table 2 provides a distinct difference between serial and habitual entrepreneurs. The benefits of serial and habitual entrepreneurs are likely to receive funding as they possess both charisma and experience (Gerpott \& Kieser, 2017). The managerial skills are more likely to influence performance on new ventures than generate ultimate success for both entrepreneurs. Thus, serial entrepreneurs accumulate knowledge and experience over each firm that he or she help found and run, thereby leading to increased returns as well as reduced risks (Sarasvathy et al., 2013). There are mentoring and business acceleration programs run by several agencies to advance the skills of entrepreneurs; these can be viewed as skills acquired by an entrepreneur that can be used for the next venture.

Therefore, serial entrepreneur behaviour may be considered a desire to exist a venture after realizing that there is no possible way forward (Wright et al., 1997).Lafontaine and Shaw (2016) claim that "serial entrepreneurs are successful because entrepreneurship is a learned skill" (p. 241).Whereas in this paper, we argue that serial entrepreneurs might be addicted to the processes involved in venture creation.

Table 2. Distinguishing serial from habitual entrepreneurs

\begin{tabular}{|l|l|}
\hline \multicolumn{1}{|c|}{ Serial entrepreneur } & \multicolumn{1}{c|}{ Habitual entrepreneur } \\
\hline $\begin{array}{l}\text { Those who have sold or closed a business in which } \\
\text { they had a minority or majority ownership stake in the } \\
\text { past, and who currently own (alone or with others) a } \\
\text { different independent business that either new, pur- } \\
\text { chased, or inherited (Westhead et al., 2005). }\end{array}$ & $\begin{array}{l}\text { Those who enjoy the venture creation process and, } \\
\text { once established, tend to hand over their ventures } \\
\text { to professional managers and go on to start others } \\
\text { (Sarasvathy et al., 2013). }\end{array}$ \\
\hline
\end{tabular}

Source: own study.

\section{Public policy encouraging failed entrepreneurs}

Failure usually yields social shame (Pretorius \& Le Roux, 2011). In the case of entrepreneurs, it is often aided by public policies providing resources and incentives to mitigate the social failure stigma towards businesses. Shane (2009) claims that "in the United States of America, the correlation across industries 
between start-up rates and failure rates is a whopping 0.77 (the correlation across countries between the percentage of value-added in total entrepreneurial activity) (p. 143)". So, by providing incentives for people to start businesses in general, we provide incentives for people to start the typical business, which is gone in a few years (Shane, 2009, p. 143).

Moreover, Shane (2009) argues that those who are likely to respond to these incentives are not the successful entrepreneurs. Public policy has several reasons in which to decide on whether to bolster entrepreneurs. For instance, it can be for the development of the previously disadvantaged people or to avoid retrenchment of employees in large numbers.

McGrath (1999) argues that failure can also provide positive consequences. Thus, avoiding to fail may contribute to unentrepreneurial activities. The underlying theme of McGrath (1999) is that failure can also be viewed from a balanced perspective. Invernizzi et al. (2017) argues that overconfidence in one's ability to determine performance may result in others praising a "superstar" that is not capable of tangible output. An example is that of Steve Jobs and his "Next Startup," which did not turn out to be a success as anticipated by entrepreneurship enthusiasts, but the incentives provided to the idea did not stop.

Failures by entrepreneurs are also visible in pitches with estimations that are designed to lure venture capitalists (McGrath, 1999). Jones and Spicer (2009) insist that "we forget that most entrepreneur's lives are not filled with success and private jets" (p.1). But slightly more failure than success. Keskin et al. (2015) confirmed that most venture capitalists are more fascinated by the personality and experience than the product, market, and business strategy. Shane (2009) blames governments in both developed and developing countries for expecting start-ups to bring about economic growth and creating employment that bolsters the incentive culture. The majority of people founding new businesses are not entrepreneurs, but rather one thing in common is that they seek self-employment funded by public policy incentives (Shane, 2009).There are several programs run by governments with the sole intention of promoting entrepreneurship without evaluation and monitoring mechanisms.

In the Belgian Flanders community, it was commonly believed that repeated entrepreneurs are bankrupt and fraudulent (Bouckaert et al., 2011). Thus, confirming that the majority of restarters are usually not capable of starting profitable businesses. As a result, The Belgian Banks are blacklisting entrepreneurs for failing to pay back loans. Whereas in Germany, it was estimated that only $3 \%$ of failed entrepreneurs restart their venture (Bouckaert et al., 2011). Thus, the German uptake of entrepreneurship by failed entrepreneurs is reasonably low.

\section{DISCUSSION}

In the quest to validate the possibility of BAE within existing studies in serial and habitual entrepreneurs, we sought to provoke further discussion in this phenomenon. The latter is neglected in entrepreneurship research despite its core agent being an entrepreneur. The entrepreneur is charged with the responsibility of society and the government to create jobs and contribute to economic growth. The examination of competence of the serial and habitual entrepreneurs are assumed to be in place when they restart or start different ventures. For this reason, studies on failure and habitual or serial entrepreneurship do not consider another possible truth such as BAE, that might well be an area to start considering if better allocation of resources for entrepreneurship need to be made in both developed and developing nations. The key definitions, such as that of the habitual and serial entrepreneurs, are yet to be clarified in literature. Thus, providing a niche for further exploration of the BAE with a particular focus on either habitual or serial entrepreneurs studied over a longitudinal period.

The role of the government towards a public policy that is in favour of incentivizing entrepreneurs should be revisited. Although the government is concerned with job creation and economic growth, they should not turn a blind eye towards unsuccessful entrepreneurs that keep applying for incentives. Monitoring these entrepreneurs will enable the government to fund genuine and successful entrepreneurs since literature suggests that those with entrepreneurial skills are likely to succeed than newentry and failed entrepreneurs. Whereas serial entrepreneurs are believed to have a slight chance of succeeding, Lafontaine and Shaw (2016) suggest that those few who succeed are likely to be the result of the funding they receive and nothing to do with their skill or luck. 
Despite great awareness of entrepreneurship by many governmental agencies, there is an apparent influx of repeated failures. There are several opportunities provided by governmental agencies and universities that are aimed at promoting successful entrepreneurship. What these programs fail to acknowledge is to assess the contribution to entrepreneurship by some of the participants. In this study, we highlighted the need to differentiate novice entrepreneurs from habitual and serial entrepreneurs. In this way, incubation hubs, acceleration programs can be focused on novice entrepreneurs who have not failed in their entrepreneurship endeavour yet.

\section{CONCLUSIONS}

This paper discussed the possibility of BAE in serial and habitual entrepreneurs. By examining this phenomenon, we can distinguish addicted entrepreneurs from habitual and serial entrepreneurs. This enabled us to further explore this area, with a specific focus on either serial or habitual entrepreneurs' addiction to entrepreneurship. Following other researchers(cf. Lafontaine \& Shaw, 2016; Rocha et al., 2015; Sarasvathy et al., 2013), we agree that the longitudinal data collection approach should be adopted over a period in studying the behavioural phenomenon. It would be of interest to explore if entrepreneurs really have competency from their previous activities and after that what makes them reenter entrepreneurship.

The addiction to entrepreneurship is thus a problematic feature of the rationale that entrepreneurs are the economic agents. Despite entrepreneurship awareness campaigns, funding opportunities and acceleration programs, the fundamental problem to entrepreneurship is repeated failure by habitual and serial entrepreneurs. Several governmental agencies are turning a blind eye to the idea of repeated entrepreneurs because they are driven by the success fallacy of entrepreneurship. It is important that BAE phenomenon is taken into account when reports on entrepreneurial activity and other government policies are written or revised.

This study, just like others, has limitations. The assumption we make is surrounding an entrepreneur, not the firm, which limits us to make assumptions about the individual, not the firm. We focus on the serial and habitual entrepreneurs, not the novice entrepreneur since the aim of the study is to display a behavioural addiction towards entrepreneurship, which is only found after repeated failure. The fact that articles were used instead of speaking to habitual entrepreneurs is also a limitation to this study, as the authors interprets the lack of reference to BAE in existing literature as a possible oversight of this construct and assumes that it might be a reason for restarting of ventures and that it can be dangerous not to acknowledge this phenomenon. This study made use of conceptual data to justify its arguments, thus limiting the findings to what is already known in the literature. The study introduced a novel concept for consideration when habitual or serial entrepreneurship is evaluated and literature search was the method.

\section{REFERENCES}

Amaral, A. M., Baptista, R., \& Lima, F. (2009). Becoming an ex-entrepreneur: firm performance and the sell-out or dissolution decision. In D. Smallbone., H. Landström.,\&D. Jones-Evans(Eds.), Entrepreneurship and growth in local, regional and national economies: Frontiers in European entrepreneurship research, (pp. 157-183). Edward Elgar.

Amaral, A. M., Baptista, R., \& Lima, F. (2011). Serial entrepreneurship: impact of human capital on time to reentry. Small Business Economics, 37(1), 1-21.

Block, J.J. (2008). Issues for DSM-V: Internet addiction. American Journal of Psychiatry,165, 306-307.

Bouckaert, A.-S., DeVreese, R., \& Smolders, C. (2011). A view on second-chance entrepreneurship in Flanders (Belgium)(Summary). Frontiers of Entrepreneurship Research, 31(21), 1.

Brandstätter, H. (2011). Personality aspects of entrepreneurship: A look at five meta-analyses. Personality and Individual Differences, 51(3), 222-230. 
Carruthers, T. J., Venter, M. W., \& Botha, M. (2019). The relationship between entrepreneurial competencies and the recurring entrepreneurial intention and action of existing entrepreneurs. The Southern African Journal of Entrepreneurship and Small Business Management, 11(1), 1-15.

Gartner, W. B. (1988). "Who is an entrepreneur?" is the wrong question. American Journal of Small Business, 12(4), 11-32.

Gerpott, F. H., \& Kieser, A. (2017). It's not charisma that makes extraordinarily successful entrepreneurs, but extraordinary success that makes entrepreneurs charismatic. Managementforschung, 27(1), 147-166.

Gompers, P., Kovner, A., Lerner, J., \& Scharfstein, D. (2006). Skill vs. luck in entrepreneurship and venture capital: Evidence from serial entrepreneurs. NBER Working Paper, No 12592.

Gottschalk, S., Greene, F. J., \& Müller, B. (2017). The impact of habitual entrepreneurial experience on new firm closure outcomes. Small Business Economics, 48(2), 303-321.

Gunnarsson, K., Vingård, E., \& Josephson, M. (2007). Self rated health and working conditions of small-scale enterprisers in Sweden. Industrial Health, 45(6), 775-780.

Invernizzi, A. C., Menozzi, A., Passarani, D. A., Patton, D., \& Viglia, G. (2017). Entrepreneurial overconfidence and its impact upon performance. International Small Business Journal, 35(6), 709-728.

Jones, C., \& Spicer, A. (2009). Unmasking the entrepreneur. Edward Elgar.

Keskin, G., Gümüşsoy, S., \& Aktekin, E. (2015). Entrepreneurship: Is it an addiction? Procedia-Social and Behavioral Sciences, 195, 1694-1697.

Lafontaine, F., \& Shaw, K. (2016). Serial entrepreneurship: Learning by doing? Journal of Labor Economics, 34(S2), S217-S254.

Logan, J. E., Leeb, R. T., \& Barker, L. E. (2009). Gender-specific mental and behavioral outcomes among physically abused high-risk seventh-grade youths. Public Health Reports, 124(2), 234-245.

Louie, R. K. (2016). The psychiatry of entrepreneurship. Academic Psychiatry, 40(2), 386-388.

McGrath, R. G. (1999). Falling forward: Real options reasoning and entrepreneurial failure. Academy of Management Review, 24(1), 13-30.

Muriithi, S. M., Ndegwa, C., \& Juma, J. (2018). Business Incubators: The Missing Link to Small Business Survival. The International Journal of Humanities \& Social Studies, 6(10), 201-209.

Pretorius, M., \& Le Roux, I. (2011). Successive failure, repeat entrepreneurship and no learning: A case study. SA Journal of Human Resource Management, 9(1), 1-13.

Rocha, V., Carneiro, A., \& Varum, C. A. (2015). Serial entrepreneurship, learning by doing and self-selection. International Journal of Industrial Organization, 40, 91-106.

Sarasvathy, S. D., Menon, A. R., \& Kuechle, G. (2013). Failing firms and successful entrepreneurs: Serial entrepreneurship as a temporal portfolio. Small Business Economics, 40(2), 417-434.

Schumpeter, J. A. (1950). Can capitalism survive?. HarperCollins Publishers.

Shane, S. (2009). Why encouraging more people to become entrepreneurs is bad public policy. Small Business Economics, 33(2), 141-149.

Spivack, A. J. (2020). Entrepreneurship Addiction and the Negative Mental Health Consequences of Entrepreneurial Engagement Among Some Entrepreneurs. In A. Örtenblad (Eds.), Against Entrepreneurship (pp. 217-232). Palgrave Macmillan.

Spivack, A. J., McKelvie, A., \& Haynie, J. M. (2014). Habitual entrepreneurs: Possible cases of entrepreneurship addiction? Journal of Business Venturing, 29(5), 651-667.

Stephan, U. (2018). Entrepreneurs' mental health and well-being: A review and research agenda. Academy of Management Perspectives, 32(3), 290-322.

Thomas, N. A., Lomberg, C., \& Alkærsig, L. (2020). Founders" Just Want to Have Fun": Substance Abuse and Entrepreneurship Addiction. Paper presented at RENT 2020.

Tipu, S. A. A. (2020). Entrepreneurial reentry after failure: a review and future research agenda. Journal of Strategy and Management, 13(2), 198-220.

Ucbasaran, D., Westhead, P., Wright, M., \& Flores, M. (2010). The nature of entrepreneurial experience, business failure and comparative optimism. Journal of Business Venturing, 25(6), 541-555.

Ucbasaran, D., Wright, M., \& Westhead, P. (2003). A longitudinal study of habitual entrepreneurs: starters and acquirers. Entrepreneurship \& Regional Development, 15(3), 207-228. 
Weiner, B. (1985). An attributional theory of achievement motivation and emotion. Psychological Review, 92(4), 549-573.

Westhead, P., Ucbasaran, D., \& Wright, M. (2005). Decisions, actions, and performance: do novice, serial, and portfolio entrepreneurs differ? Journal of Small Business Management, 43(4), 393-417.

Westhead, P., Ucbasaran, D., Wright, M., \& Binks, M. (2005). Novice, serial and portfolio entrepreneur behaviour and contributions. Small Business Economics, 25(2), 109-132.

Wright, M., Robbie, K., \& Ennew, C. (1997). Venture capitalists and serial entrepreneurs. Journal of Business Venturing, 12(3), 227-249.

Wright, M., \& Westhead, P. (2016). The Habitual Entrepreneur. Routledge. 


\section{Authors}

The contribution share of authors is equal and amounted to $1 / 3$ for each of them.

\section{Ndivhuho Tshikovhi}

Postdoctoral fellow at the Durban University of Technology, South Africa. He holds a doctorate in social and political sciences. His research interests includes entrepreneurship, public policy and behavioural addiction to entrepreneurship.

Correspondence to: Dr Ndivhuho Tshikovhi, Durban University of Technology, 41 - 43 ML Sultan Road, Durban 4001, South Africa. Email NdivhuhoT@dut.ac.za

ORCID (1) http://orcid.org/0000-0002-3647-9223

\section{Farai Dziike}

Social innovation lab coordinator at the Durban University of Technology. He holds a PhD in Materials Chemistry. His research interests includes nanomaterial science., electrochemistry and catalyst synthesis.

Correspondence to: Dr Farai Dziike, Research and Postgraduate Support, Steve Biko Campus, Durban University of Technology, Durban 4000, South Africa. Email FaraiD1@dut.ac.za

ORCID (1) http://orcid.org/0000-0002-3030-6268

\section{Sibusiso Moyo}

Deputy vice-chancellor: research, innovation and engagement at the Durban University of Technology. She holds a PhD in Mathematics. Her research interests includes mathematics, entrepreneurship and higher institutions of learning.

Correspondence to: Prof Sibusiso Moyo, Office of the DVC Research, Innovation and Engagement \& Institute for Systems Science, Milena Court, Steve Biko Campus, Durban University of Technology Durban 4000, South Africa.Email dvcrie@dut.ac.za

ORCID (1) http://orcid.org/0000-0001-5613-7290

\section{Acknowledgements and Financial Disclosure}

The authors would like to thank the anonymous referees for their useful comments, which allowed to increase the value of this article.

\section{Conflict of Interest}

The authors declare that the research was conducted in the absence of any commercial or financial relationships that could be construed as a potential conflict of interest.

\section{Copyright and License}

This article is published under the terms of the Creative Commons

Attribution - NoDerivs (CC BY-ND 4.0) License

http://creativecommons.org/licenses/by-nd/4.0/ 